\title{
Study to Elucidate the Inhibitory Potential of Selected Flavonoids against Jab1 in Cervical Cancer
}

\author{
Pooja Maurya ${ }^{1}$, Pratibha Pandey 1,*(D), Fahad Khan 1,*, Rashmi Mishra ${ }^{1}$, Rohit Chaudhary ${ }^{2}$, Sujeet \\ Kumar Singh 1
}

1 Department of Biotechnology, Noida Institute of Engineering and Technology, Greater Noida

2 Department of Computer Science and Engineering, Noida Institute of Engineering and Technology, Greater Noida

* Correspondence: shukla.pratibha1985@gmail.com (P.P.); fahadintegralian@gmail.com (F.K.);

Scopus Author ID 54985258500 (P.P.); 57201049984 (F.K.)

Received: 15.03.2021; Revised: 16.04.2021; Accepted: 20.04.2021; Published: 26.04.2021

\begin{abstract}
Jab1 has gained tremendous attention as a potent target in cancer therapeutics. Jab1 has been associated with the progression of numerous carcinomas by exhibiting several negative roles, such as degradation of tumor suppressor genes. We have mainly focused our research on elucidating inhibitory phytocompound (flavonoid) that could inhibit the Jab1 expression in cervical cancer, one of the most globally recognized gynecologic malignancies. Moreover, this study would provide a better targeted therapeutic approach for the management of cervical cancer. Although numerous flavonoids have presented potent cytotoxic and antitumor efficacy against HeLa cells, the inhibitory potential of some flavonoids against Jab1 has not been explored yet. Therefore, the current research aims to explore the inhibitory potential of flavonoids against Jab1 in cervical cancer. A total of eleven potent phytocompounds have been selected for screening potent phytocompound that could inhibit HeLa cancer cell growth via Jab1 downregulation. In silico findings demonstrated baicalein as the best Jab1 inhibitory phytocompound. Additionally, MTT assay and RT-PCR analysis have also strongly validated its inhibitory potential against Jab1 in cervical cancer. However, the further detailed analysis needed to be done to elucidate a novel mechanism that could help identify a novel and potent therapeutic phytocompound for drug development against cervical cancer.
\end{abstract}

Keywords: Jab1; Flavonoids; molecular docking; MTT; RT PCR; cervical cancer.

(C) 2021 by the authors. This article is an open-access article distributed under the terms and conditions of the Creative Commons Attribution (CC BY) license (https://creativecommons.org/licenses/by/4.0/).

\section{Introduction}

Jab1 has emerged as a potential oncotarget in the management of several chemotherapeutic approaches [1]. Aberrant increase in cervical cancer incidences has demanded extreme attention globally [2]. Considering the numerous side effects of conventional therapies, the current research is focused on identifying novel phytocompounds targeting these crucial oncotargets involved in cancer progression [3-4]. Interestingly, Jab1 (CSN5) has been known to play a significant role in cell cycle regulation, DNA damage repair, cellular differentiation, and apoptosis [5]. Indeed, our previously published study has also demonstrated its significant involvement in gall bladder cancer progression [6]. This multifunctional oncoprotein has played a crucial role in the progression of several carcinomas, including cervical cancer, making it imperative to screen phytocompounds that can downregulate its expression in cervical cancer [7,8].

Natural compounds have displayed significant potential in apoptotic induction in cancerous cells by altering various crucial components of signaling pathways and emerged as 
potent chemopreventive agents $[9,10]$. Phytocompounds exhibit several benefits, including limited toxicity, easy availability, and minimal cost, which supported their potential in managing numerous carcinomas [11]. Flavonoids have gained wider attention by displaying significant apoptosis-inducing efficacy in several cancer cell lines such as LNCaP (human prostate cancer cell), MDA-MB-231 (human breast cancer cell), HT-29 (human colon cancer cell) $[12,13]$. Although flavonoids have been well known for their anticancerous potential in HeLa cells, the inhibitory potential of Flavonoids against Jab1 in HeLa cancer cells remains unelucidated $[14,15]$. Thus, our study is mainly targeted to elucidate the inhibitory efficacy of selected Flavonoids against Jab1 in HeLa cancer cells.

The development of novel anticancerous drugs is a very time-consuming and costlier task; therefore, a systematic and planned approach is required for rational drug discovery to conquer the limitations associated with chemotherapeutic approaches. In silico approaches, employing medicinal benefits of phytocompounds has been a fundamental element of drug designing and development in this era of personalized medicine, cost, and effective health outcomes [16-19]. To date, very few studies have reported the inhibitory potential of these selected Flavonoids against Jab1 in cervical cancer. In this research report, eleven potent Flavonoids were selected for finding their inhibitory potential against Jab1 in cervical cancer using several in silico and in vitro approaches. However, more in vitro experimentation needed to be performed to gain detailed insight into the mechanism involved.

\section{Materials and Methods}

\subsection{Tools required for in silico study.}

Windows, MGL tools, Autodock 4.2, Discovery Studio Visualizer, PatchDock online server, Cygwin and Binary files

\subsection{Ligand (Flavonoids) preparation.}

Eleven potent flavonoids have been selected through literature sources (Table 1), and their 3D structures were obtained from PubChem (https://pubchem.ncbi.nlm.nih.gov/) database. Energy minimization of selected phytoligands was performed before docking [20].

\subsection{Preparation of target protein (macromolecule).}

The 3D crystal structure of Jab1 (PDB ID: 4F7O) was obtained from PDB (Protein Data Bank) (http://www.rcsb.org/pdb). Energy minimization and refinement of the 3D structure of Jab1 were done before performing docking. The refinement process was performed by adding Kollman charges and polar hydrogen atoms and removing crystallographic water molecules from the protein.

\subsection{Molecular docking analysis using AutoDock 4.2 and PatchDock software.}

Molecular docking of selected eleven phytocompounds and two standard drugs against Jab1 (target proteins) was done using AutoDock 4.2 [21]. Autogrid was utilized to identify the position of ligand on the binding site of Jab1 protein with grid spacing $0.375 \AA$ and grid coordinates (X, Y, and Z) axes. After analyzing the binding of eleven phytocompounds with Jab1 using AutoDock 4.2 and PatchDock software, baicalein has displayed maximum binding affinity against Jab1. 
Table 1. List of ten screened phytocompounds (Flavonoids).

\begin{tabular}{|c|c|c|c|}
\hline S. No & Name of compounds & Pubchem ID & 3d structure \\
\hline 1. & Hesperidin & 10621 & \\
\hline 2. & Curcumin & 969516 & \\
\hline 3. & Apigenin & 5280443 & \\
\hline 4. & Naringin & 442428 & \\
\hline 5. & Quercetin & 5280343 & \\
\hline 6. & Luteolin & 5280445 & \\
\hline
\end{tabular}




\begin{tabular}{|c|c|c|c|}
\hline S. No & Name of compounds & Pubchem ID & 3d structure \\
\hline 7. & Myricetin & 5281672 & \\
\hline 8. & Cyanidin & 128861 & \\
\hline 9. & EGCG & 65064 & \\
\hline 10. & Baicalein & 5281605 & \\
\hline 11. & Genistein & 5280961 & \\
\hline
\end{tabular}

2.5. PASS (prediction of activity spectra for substances) analysis.

PASS analysis was done to predict the biological activity spectrum of phytocompound based on its SAR (structure-activity relationship) with a known chemical entity [22]. Several online and offline tools were utilized to perform PASS analysis, as mentioned below.

\subsubsection{Lipinski's rule of five.}

Druglikeness of selected eleven phytocompounds and two standard conventional drugs were elucidated using Lipinski's rule of five [23]. Parameters considered for analyzing druglikeness were MW, number of $\mathrm{H}$ (hydrogen) bond donors, $\log \mathrm{P}, \mathrm{H}$ (hydrogen) bond acceptor sites, number of rotatable bonds, and TPSA (topological polar surface area). Molinspiration 
(http://www.molinspiration.com/cgi-bin/properties ) tool was used to calculate the druglikeness of selected phytocompounds.

\subsection{Bioactivity score $(B A S)$ prediction.}

BAS values predict the overall ability of phytocompound to be a potent lead (drug) candidate. Molinspiration chemoinformatics (an online tool) (https://www.molinspiration.com/cgi-bin/properties) was utilized to assess the drug score of prospective phytocompound with respect to various human receptors, including ion channels, GPCRs, enzymes, kinases, proteases, and nuclear receptors. In general, a higher bioactivity score exhibits a greater probability of the active compound being active [24].

\subsection{Pharmacokinetic (PK) parameters analysis.}

ADMET properties of all the components, including and standard drugs and selected phytocompounds were predicted using SwissADME software (http://www.swissadme.ch/). This online software analyses several key pharmacokinetic properties of a compound such as BBB (blood-brain barrier), LogKp (skin permeability), and its metabolism in terms of it being a Cytochrome P450 (CYP2C19, CYP1A2, CYP2D6, CYP2C9, CYP3A4) inhibitor, P-gp (Pglycoprotein substrate) [25].

\subsection{Cell line and cell culture.}

HeLa cancer cells were procured from NCCS (National Centre for Cell Science, Pune), India. HeLa cells were maintained in RPMI-1640 medium (supplemented with $100 \mathrm{U} / \mathrm{mL}$ of penicillin, $10 \%$ Fetal Bovine Serum (FBS), and $100 \mu \mathrm{g} / \mathrm{mL}$ of streptomycin) and were grown in an incubator (at $5 \% \mathrm{CO}_{2}$ and $37{ }^{\circ} \mathrm{C}$ temperature).

\subsection{MTT analysis.}

The effect of best-screened flavonoid amongst selected flavonoids on HeLa cell viability was investigated by MTT assay as described earlier [26]. HeLa cells were stored for $24 \mathrm{~h}$ in an incubator and after $24 \mathrm{~h}$ of overnight incubation, cells were treated with baicalein and thereafter with MTT dye. Lastly, the treated cells were left incubated for $4 \mathrm{~h}$, and absorbance was recorded at $540 \mathrm{~nm}$ (using a microplate reader, BioRad, USA).

\subsection{RT-PCR analysis.}

To further validate whether screened compounds via in silico analysis possess significant inhibitory potential against Jab1 mRNA expression, RT-PCR was performed on baicalein-treated HeLa cells [27]. HeLa cancer cells $\left(1 \times 10^{6}\right)$ were grown in $75 \mathrm{~cm}^{2}$ flasks and left for adherence for $24 \mathrm{~h}$. Afterward, the cells were then treated with selective doses of a screened compound or DMSO control for $24 \mathrm{~h}$. Treated cells were then washed with $5 \mu \mathrm{L}$ PBS and trypsinized. The cancer cell suspension was then centrifuged (at $350 \mathrm{x}$ g for 3 minutes), and the obtained cell pellet was resuspended in PBS (ice-cold) buffer. The cell suspension was further centrifuged (at $17000 \mathrm{x}$ g for $3 \mathrm{~min}$ at $4{ }^{\circ} \mathrm{C}$ ). Obtained pellet was stored at $-80{ }^{\circ} \mathrm{C}$ for future analysis. Total RNA was extracted after $24 \mathrm{~h}$ of baicalein treatment using TRIzol Reagent (Invitrogen) as per the manufacturer's protocol. RT-PCR was used using one-step RTPCR (SuperScript III) with Platinum Taq DNA polymerase kit (12574-018; Invitrogen). 
Relative expression was calculated by the $2(\Delta \Delta \mathrm{Ct})$ method. Primers used in this study are (Table 2):

Table 2. Primer used for RT-PCR analysis.

\begin{tabular}{l|l|l} 
Gene & \multicolumn{1}{|c|}{ Forward Primer } & \multicolumn{1}{c}{ Reverse Primer } \\
\hline Jab1 & 5'-GGCGCCTTTAGGACATACC -3' & 5'- CATGAAACTCCCTCGTCCC -3' \\
\hline$\beta$-actin & 5'-GTCTGTGATGCCCTTAGATG-3' & 5'-AGCTTATGACCCGCACTTAC-3'
\end{tabular}

\section{Results and Discussion}

\subsection{Docking analysis of selected Flavonoids against Jab1.}

AutoDock 4.2 and PatchDock were utilized for the docking study of selected phytocompounds against Jab1 (Table 1 and Table 2). As is evident from Table 3, all selected eleven phytocompounds exhibited significant binding affinity to Jab1 based on the dissociation constant $(\mathrm{Kd})$ and best binding energy of ligand-protein interactions. However, baicalein displayed the highest binding energy against Jab1 in comparison to standard drugs. Obtained docking results were visualized in the Discovery Studio Visualizer.

\subsection{BAS Score of selected phytocompounds (Flavonoids).}

Predicted BAS (Bioactivity score) of all selected phytocompounds and standard drugs are tabulated in Table 6. In general, a compound having BAS $>0.00$ possesses significant biological potential, whereas compounds with values ranges between 0.50 and 0.00 are considered to be moderately active. Compounds having BAS $<0.50$ are considered to be inactive. Our findings strongly demonstrated that all selected phytocompounds are biologically active molecules as per the standard criteria described above. However, baicalein displayed the best potential to provide physiological actions via numerous mechanisms after interacting with nuclear receptor ligands, GPCR ligands, or acting as enzyme inhibitors.

Table 3. Docking analysis of selected eleven phytocompounds with Jab1 using AutoDock and PatchDock

\begin{tabular}{l|l|l|l|l|l|l}
\multirow{2}{*}{ S.NO } & \multicolumn{2}{c}{ Ligand } & \multicolumn{3}{c}{ Software. } \\
\cline { 3 - 6 } & & $\begin{array}{c}\text { Autodock 4.2 } \\
\text { Binding } \\
\text { energy } \\
\text { kcal/mol }\end{array}$ & $\begin{array}{c}\text { Total } \\
\text { internal } \\
\text { energy }\end{array}$ & $\begin{array}{c}\text { Inhibitor } \\
\text { constant }\end{array}$ & Score & ACE \\
\hline 1. & Hesperidin & -5.75 & 1.45 & 61.35 & 3768 & -84.32 \\
\hline 2. & Curcumin & -5.59 & 1.12 & 79.36 & 4150 & -80.01 \\
\hline 3. & Apigenin & -6.29 & 0.7 & 24.37 & 6444 & -147.12 \\
\hline 4. & Naringin & -5.72 & 1.69 & 64.54 & 6690 & -66.87 \\
\hline 5. & Quercetin & -6.47 & 0.99 & 18.04 & 5800 & -100.49 \\
\hline 6. & Luteolin & -6.48 & 0.43 & 17.68 & 4338 & -43.60 \\
\hline 7. & Myricetin & -6.45 & 1.25 & 18.72 & 4466 & -63.28 \\
\hline 8. & Cyanidin & -6.95 & 0.54 & 7.99 & 4368 & -46.39 \\
\hline 9. & EGCG & -6.21 & 1.02 & 28.21 & 5584 & -91.66 \\
\hline $\mathbf{1 0 .}$ & Baicalein & $-\mathbf{7 . 2}$ & $\mathbf{1 . 2 6}$ & $\mathbf{5 . 3 1}$ & $\mathbf{4 4 0 6}$ & $\mathbf{- 8 0 . 9 3}$ \\
\hline 11. & Genistein & -6.59 & 0.74 & 14.65 & 4292 & -47.51 \\
\hline 12. & Doxorubicin & -7.19 & 1.9 & 3.21 & 4406 & -80.93 \\
\hline 13. & 5 fluorouracil & -3.46 & 0.0 & 2.9 & 2548 & 38.81
\end{tabular}

3.2. PASS analysis of selected phytocompounds (Flavonoids) using Lipinski's rule of five.

Lipinski's rule of five explains the molecular properties of a compound that are crucial for lead optimization and selectivity in clinical applications. Table 5 displays PASS analysis of selected phytocompounds versus standard drugs in terms of their physicochemical properties. 
Usually, any orally active lead candidate should not have more than 1 Lipinski's violation, or else its bioavailability would be compromised. Interestingly, baicalein exhibited no Lipinski's violation in comparison to all other screened phytocompound and standard drugs, thereby strongly representing it as a strong drug candidate for the management of cervical cancer.

Table 4. AutoDock and PatchDock analysis.

\begin{tabular}{|c|c|c|c|}
\hline S.No. & Compound & AutoDock & PatchDock \\
\hline 1. & Hesperidin & & \\
\hline 2. & Curcumin & & \\
\hline 3. & Apigenin & & \\
\hline 4. & Naringin & & \\
\hline
\end{tabular}




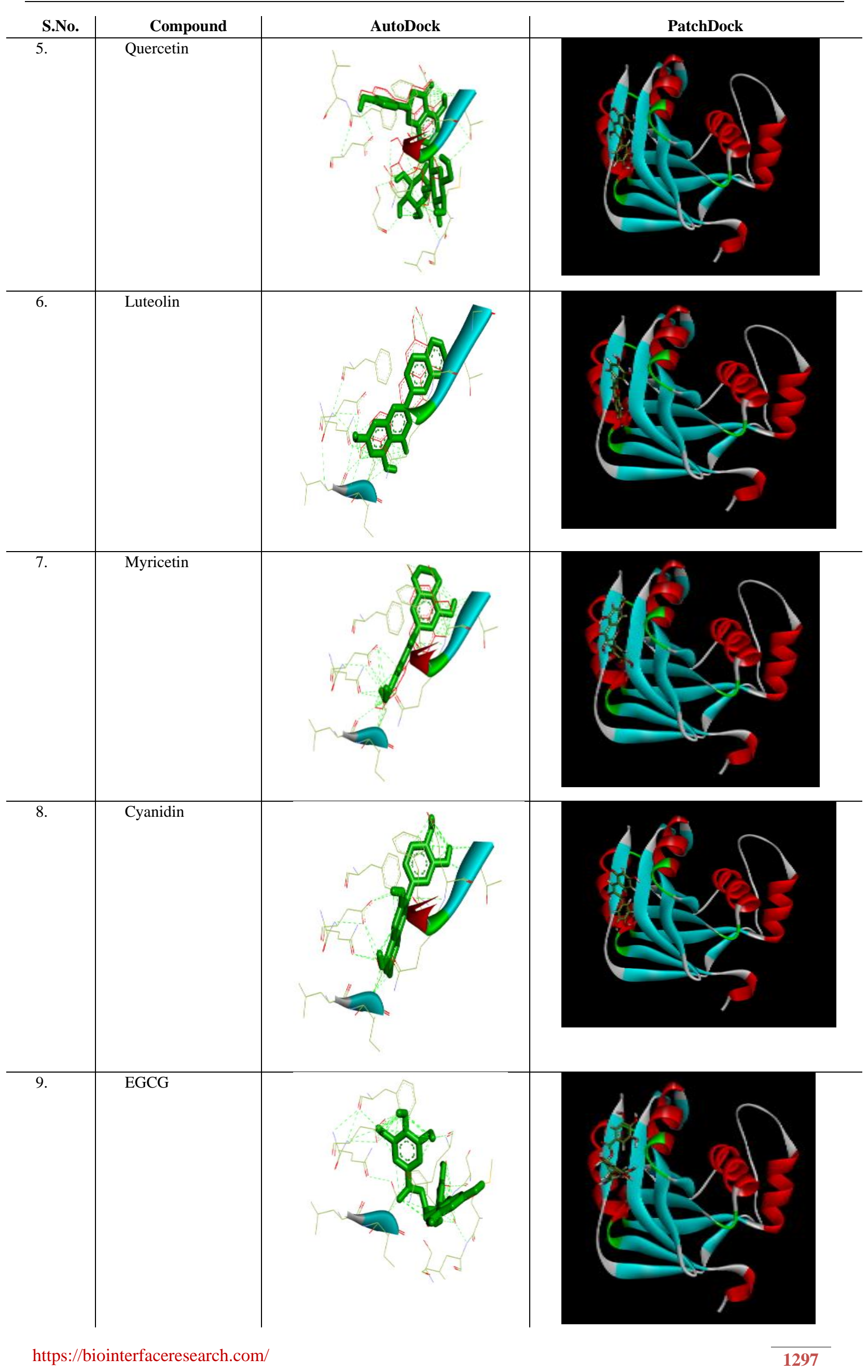




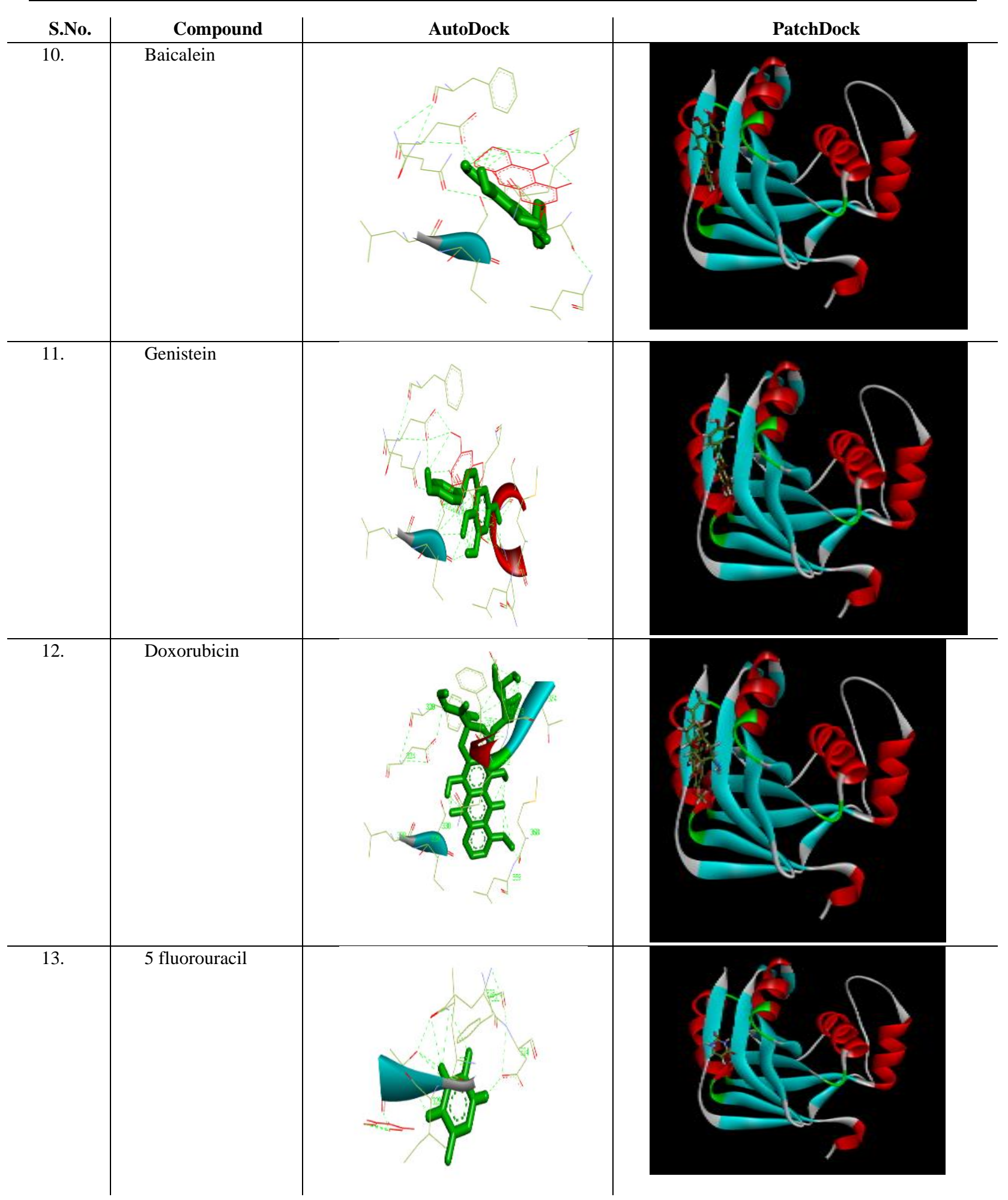

Table 5. PASS analysis of selected phytocmpounds (Flavonoids).

\begin{tabular}{l|l|l|l|l|l|l|l|l|l} 
S.No & Ligand & $\begin{array}{l}\text { No of } \\
\text { heavy } \\
\text { atoms }\end{array}$ & $\begin{array}{l}\text { Molecular } \\
\text { weight } \\
\text { g/mol }\end{array}$ & TPSA & $\begin{array}{l}\text { Log p- } \\
\text { value }\end{array}$ & $\begin{array}{l}\text { H-bond } \\
\text { donor }\end{array}$ & $\begin{array}{l}\text { H-bond } \\
\text { acceptor }\end{array}$ & $\begin{array}{l}\text { Number } \\
\text { rotational } \\
\text { bonds }\end{array}$ & $\begin{array}{l}\text { Lipinski's } \\
\text { violation }\end{array}$ \\
\hline 1. & Hesperidin & 43 & 610.56 & 234.25 & -1.1 & 8 & 15 & 7 & 3 \\
\hline 2. & Curcumin & 27 & 368.38 & 93.06 & 3.2 & 2 & 6 & 8 & 0 \\
\hline 3. & Apigenin & 20 & 270.24 & 90.90 & 1.7 & 3 & 5 & 1 & 0 \\
\hline 4. & Naringin & 41 & 580.53 & 225.06 & -0.5 & 8 & 14 & 6 \\
\hline 5. & Quercetin & 22 & 302.24 & 131.36 & 1.5 & 5 & 7 & 1 & 3 \\
\hline 6. & Luteolin & 21 & 286.24 & 111.13 & 1.4 & 4 & 6 & 0 \\
\hline 7. & Myricetin & 23 & 318.24 & 151.59 & 1.2 & 6 & 8 & 1 & 1 \\
\hline 8. & Cyanidin & 21 & 287.24 & 114.29 & ------- & 5 & 6 & 1 & 1 \\
\end{tabular}




\begin{tabular}{l|l|l|l|l|l|l|l|l|l} 
S.No & Ligand & $\begin{array}{l}\text { No of } \\
\text { heavy } \\
\text { atoms }\end{array}$ & $\begin{array}{l}\text { Molecular } \\
\text { weight } \\
\text { g/mol }\end{array}$ & TPSA & $\begin{array}{l}\text { Log p- } \\
\text { value }\end{array}$ & $\begin{array}{l}\text { H-bond } \\
\text { donor }\end{array}$ & $\begin{array}{l}\text { H-bond } \\
\text { acceptor }\end{array}$ & $\begin{array}{l}\text { Number } \\
\text { rotational } \\
\text { bonds }\end{array}$ & $\begin{array}{l}\text { Lipinski's } \\
\text { violation }\end{array}$ \\
\hline 9. & EGCG & 33 & 458.37 & 197.37 & 1.2 & 8 & 11 & 4 & 2 \\
\hline 10. & Baicalein & 20 & 270.24 & 90.90 & 1.7 & 3 & 5 & 1 & 0 \\
\hline 11. & Genistein & 20 & 270.24 & 90.90 & 2.7 & 3 & 5 & 1 & 0 \\
\hline 12. & Doxorubicin & 39 & 543.52 & 206.07 & 1.3 & 6 & 12 & 5 & 3 \\
\hline 13. & 5 fluorouracil & 9 & 130.08 & 65.72 & 0.9 & 2 & 3 & 0 & 0
\end{tabular}

Table 6. BAS (Bioactivity score) of all selected phytocompounds (Flavonoids).

\begin{tabular}{c|l|l|l|l|l|l|l} 
S. No & Ligand & GPCR & $\begin{array}{l}\text { Ion channel } \\
\text { modulator }\end{array}$ & $\begin{array}{l}\text { Kinase } \\
\text { inhibitor }\end{array}$ & $\begin{array}{l}\text { Nuclear } \\
\text { acceptor } \\
\text { ligand }\end{array}$ & $\begin{array}{l}\text { Protease } \\
\text { inhibitor }\end{array}$ & $\begin{array}{l}\text { Enzyme } \\
\text { inhibitor }\end{array}$ \\
\hline 1. & Hesperidin & -0.01 & -0.59 & -0.36 & -0.20 & -0.00 & 0.06 \\
\hline 2. & Curcumin & -0.06 & -0.20 & -0.26 & -0.12 & -0.14 & 0.08 \\
\hline 3. & Apigenin & -0.07 & -0.09 & 0.18 & 0.34 & -0.25 & 0.26 \\
\hline 4. & Naringin & 0.11 & -0.40 & -0.24 & 0.04 & 0.09 & 0.24 \\
\hline 5. & Quercetin & -0.06 & -0.19 & 0.28 & 0.36 & -0.25 & 0.28 \\
\hline 6. & Luteolin & -0.02 & -0.07 & 0.26 & 0.39 & -0.22 & 0.28 \\
\hline 7. & Myricetin & -0.06 & -0.18 & 0.28 & 0.32 & -0.20 & 0.30 \\
\hline 8. & Cyanidin & -0.13 & -0.09 & 0.02 & 0.09 & -0.30 & 0.01 \\
\hline 9. & EGCG & 0.16 & 0.02 & 0.06 & 0.33 & 0.13 & 0.25 \\
\hline 10. & Baicalein & -0.12 & -0.18 & 0.19 & 0.17 & -0.35 & 0.26 \\
\hline 11. & Genistein & -0.22 & -0.54 & -0.06 & 0.23 & -0.68 & 0.13 \\
\hline 12. & 5 fluorouracil & -2.60 & -1.95 & -2.62 & -3.04 & -3.15 & -1.56
\end{tabular}

3.4. ADMET (absorption, distribution, metabolism, excretion and toxicity) properties of phytocomponents.

The pharmacokinetics feasibility of all eleven selected phytocompounds (as a prospective lead candidate) was calculated using online SwissADME software (Table 7). LogP value indicated the lipophilic (lipid-soluble) and good absorption nature of phytocompound across the skin. Interestingly, none of the phytocompounds displayed BBB (blood-brain barrier) permeability as well as behaved as P-gp (permeability-glycoprotein) substrates except three phytocompound and standard drug. P-gp (an ATP-dependent bioavailability protein pump) removes drugs from biological systems. Normal excretion of potential drugs back into the lumen (gut) by P-gp reduces the pharmacokinetics efficacy of pharmaceutical drugs (that are known to be P-gp substrates). CYPs (Cytochromes P450) are a superfamily of metabolic enzymes associated with xenobiotics biotransformation. Compounds that inhibited five classes of CYPs (CYP3A4, CYP1A2, CYP2C9, CYP2C19, and CYP2D6) would cause enhanced plasma concentrations, thereby contributing to improved bioavailability. Kp (Skin permeability) is mainly used to describe quantitative chemical permeation through the epidermis or outermost layer of skin.

Table 7. Pharmacokinetic feasibility of all eleven selected phytocompounds (Flavonoids).

\begin{tabular}{|c|c|c|c|c|c|c|c|c|c|c|}
\hline S. No & Ligand & $\begin{array}{l}\text { Lipophi } \\
\text { licity }\end{array}$ & $\begin{array}{l}\text { BBB } \\
\text { Permeant }\end{array}$ & $\begin{array}{l}\text { p- } \quad \text { gp } \\
\text { substrate }\end{array}$ & $\begin{array}{l}\text { Cyp1A2 } \\
\text { Inhibitor }\end{array}$ & $\begin{array}{l}\text { Cyp2c19 } \\
\text { Inhibitor }\end{array}$ & $\begin{array}{l}\text { Cyp2c9 } \\
\text { Inhibitor }\end{array}$ & $\begin{array}{l}\text { Cyp2D6 } \\
\text { Inhibitor }\end{array}$ & $\begin{array}{l}\text { Cyp3A4 } \\
\text { Inhibitor }\end{array}$ & $\begin{array}{l}\log \quad \mathrm{kp} \\
(\mathrm{cm} / \mathrm{s})\end{array}$ \\
\hline 1 & Hesperidin & -0.72 & No & Yes & No & No & No & No & No & -10.12 \\
\hline 2 & Curcumin & 3.03 & No & No & No & No & Yes & No & Yes & -6.28 \\
\hline 3 & Apigenin & 2.11 & No & No & Yes & No & No & Yes & Yes & -5.80 \\
\hline 4 & Naringin & -0.79 & No & Yes & No & No & No & No & No & -10.15 \\
\hline 5 & Quercetin & 1.23 & No & No & Yes & No & No & Yes & Yes & -7.05 \\
\hline 6 & Luteolin & 1.73 & No & No & Yes & No & No & Yes & Yes & -6.25 \\
\hline 7 & Myricetin & 0.79 & No & No & Yes & No & No & No & Yes & -7.40 \\
\hline 8 & Cyanidin & 0.56 & No & Yes & Yes & No & No & No & No & -6.67 \\
\hline
\end{tabular}




\begin{tabular}{l|l|l|l|c|c|c|c|c|c|c} 
S. No & Ligand & $\begin{array}{l}\text { Lipophi } \\
\text { licity }\end{array}$ & $\begin{array}{l}\text { BBB } \\
\text { Permeant }\end{array}$ & $\begin{array}{l}\text { p- gp } \\
\text { substrate }\end{array}$ & $\begin{array}{l}\text { Cyp1A2 } \\
\text { Inhibitor }\end{array}$ & $\begin{array}{l}\text { Cyp2c19 } \\
\text { Inhibitor }\end{array}$ & $\begin{array}{l}\text { Cyp2c9 } \\
\text { Inhibitor }\end{array}$ & $\begin{array}{l}\text { Cyp2D6 } \\
\text { Inhibitor }\end{array}$ & $\begin{array}{l}\text { Cyp3A4 } \\
\text { Inhibitor }\end{array}$ & $\begin{array}{l}\text { Log } \\
\text { (cm/s) }\end{array}$ \\
\hline 9 & EGCG & 1.01 & No & No & No & No & No & No & No & -8.27 \\
\hline 10 & Baicalein & 2.24 & No & No & Yes & No & No & Yes & Yes & -5.70 \\
\hline 11 & Genistein & 2.04 & No & No & Yes & No & No & Yes & Yes & -6.05 \\
\hline 12 & Doxorubicin & 0.44 & No & Yes & No & No & No & No & No & -8.71 \\
\hline 13 & 5 fluorouracil & 0.13 & No & No & No & No & No & No & No & -7.73
\end{tabular}

\subsection{MTT analysis to study growth arrest in baicalein-treated HeLa cells.}

Cytotoxic or growth arrest potential of baicalein in HeLa cancer cells was determined by treating cancer cells with selective baicalein doses $(0,25,50,75,100$, and $200 \mu \mathrm{M})$ for 24 and $48 \mathrm{~h}$. Evaluated data displayed significant growth arrest in baicalein-treated HeLa cancer cells compared to control (Figure 1) according to earlier research reports [28].

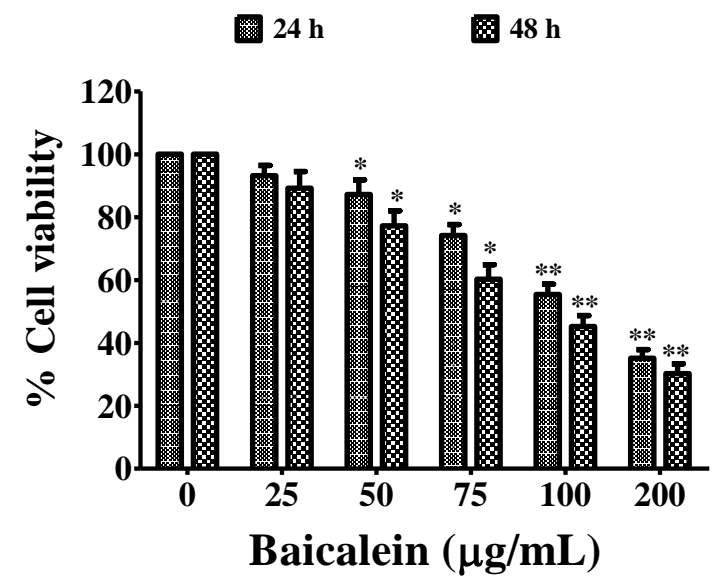

Figure 1. Dose and time-dependent efficacy of Baicalein on HeLa cancer cells. Percent (\%) cell viability of baicalein treated HeLa cells $(0-200 \mu \mathrm{M})$ for 24 and $48 \mathrm{~h}$ assessed by MTT assay. Obtained results are visualized as mean \pm SEM of experiments performed independently in triplicate $(* \mathrm{P}<0.01, * * \mathrm{P}<0.001$ denoted considerable difference in comparison to control).

\subsection{RT-PCR analysis to study gene expression}

Because baicalein exhibited significant Jab1 inhibitory potential in silico analysis, therefore, we further performed RT-PCR analysis to validate the inhibitory potential of baicalein against Jab1 mRNA expression in HeLa cancer cells. Baicalein treatment resulted in significantly downregulated Jab1 mRNA expression in HeLa cells (Figure 2) in comparison to untreated (control) cells.

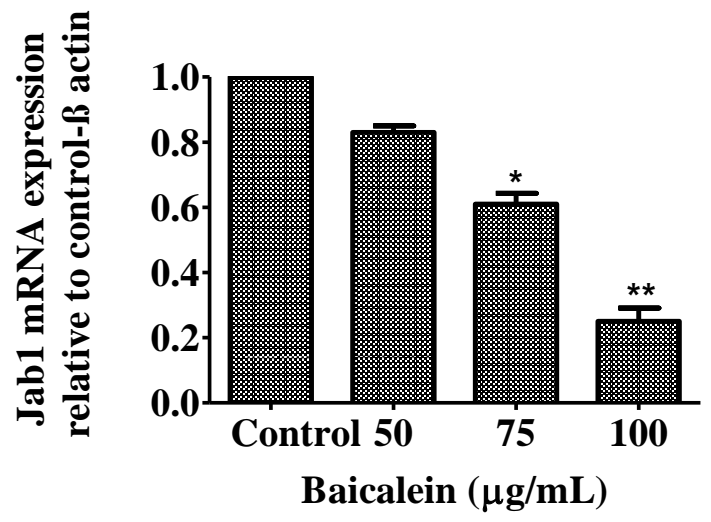

Figure 2. Differential expression analysis of JAB1 mRNA in baicalein treated cells by real-time PCR in HeLa cancer cells values are presented as mean \pm SEM of three independent experiments $(* \mathrm{P}<0.05, * * \mathrm{P}<0.01$

compared to negative control). 
Altogether, both in silico and in vitro findings have strongly revealed that baicalein could be a potential Jab1 inhibitor. Since Jab1 has been positively associated with cervical cancer cell growth [29], hence our experimental findings provided a potent phytocompound as a potent lead candidate that can not only display growth arrest in HeLa cancer cells but also suppress the overexpression of Jab1 oncogene that has been crucially involved in the progression of cervical cancer. However, more in vitro experiments are needed to explain the mechanism associated with the inhibitory potential of Baicalein against Jab1 in cervical cancer.

\section{Conclusions}

Our experimental findings endeavored to elucidate the inhibitory potential of phytocompounds (Flavonoids) against Jab1 oncogene that has been crucially associated with several cancer progressions. We have selected eleven Flavonoids for our investigation, and interestingly, both in silico and in vitro findings strongly validated the Jab1 inhibitory potential of baicalein amongst all other selected phytocompound, thereby revealing it as a strong lead candidate for the management of cervical cancer disease.

\section{Funding}

This research received no external funding.

\section{Acknowledgments}

The authors thank Noida Institute of Engineering \& Technology management for providing the facilities to carry out this study.

\section{Conflicts of Interest}

The authors declare no conflict of interest.

\section{References}

1. Hou, J.; Liu, G.; Yuan, Y.; Wang, D.; Jiao, P.; Xing, L.; Pan, Y. Increased Jab1/COPS5 is associated with therapeutic response and adverse outcome in lung cancer and breast cancer patients. Oncotarget 2017, 8, 97504, https://doi.org/10.18632/oncotarget.22146.

2. Woo, Y.L.; Gravitt, P.; Khor, S.K.; Ng, C.W.; Saville, M. Accelerating action on cervical screening in lowerand middle-income countries (LMICs) post COVID-19 era. Prev. Med. 2021, 144, 106294, https://doi.org/10.1016/j.ypmed.2020.106294.

3. Shin, E.; Lim, D.H.; Han, J.; Nam, D.-H.; Park, K.; Ahn, M.-J.; Kang, W.K.; Lee, J.; Ahn, J.S.; Lee, S.-H.; Sun, J.-M.; Jung, H.A.; Chung, T.-Y. Markedly increased ocular side effect causing severe vision deterioration after chemotherapy using new or investigational epidermal or fibroblast growth factor receptor inhibitors. BMC Ophthalmol. 2020, 20, 19, https://doi.org/10.1186/s12886-019-1285-9.

4. Bose, S.; Banerjee, S.; Mondal, A.; Chakraborty, U.; Pumarol, J.; Croley, C.R.; Bishayee, A. Targeting the JAK/STAT Signaling Pathway Using Phytocompounds for Cancer Prevention and Therapy. Cells 2020, 9 , https://doi.org/10.3390/cells9061451.

5. Samsa, W.E.; Mamidi, M.K.; Bashur, L.A.; Elliott, R.; Miron, A.; Chen, Y.; Lee, B.; Greenfield, E.M.; Chan, R.; Danielpour, D.; Zhou, G. The crucial p53-dependent oncogenic role of JAB1 in osteosarcoma in vivo. Oncogene 2020, 39, 4581-4591, https://doi.org/10.1038/s41388-020-1320-6.

6. Pandey, P.; Khan, F. Jab1 Inhibition by Methanolic Extract of Moringa Oleifera Leaves in Cervical Cancer Cells: A Potent Targeted Therapeutic Approach. Nutr. Cancer 2020, 19,https://doi.org/10.1080/01635581.2020.1826989. 
7. Shen, Q.; Shang, B.; Jiang, B.; Wang, Y.; Wang, Z.; Chen, G. Overexpression of JAB1 promotes malignant behavior and predicts poor prognosis in esophageal squamous cell carcinoma. Thoracic Cancer 2020, 11, 973-982, https://doi.org/10.1111/1759-7714.13350.

8. Shi, D.; Mu, S.; Hu, B.; Zhang, S.; Liu, J.; Zhang, Z.; Shao, Z. Prognostic role of c-Jun activation domainbinding protein-1 in cancer: A systematic review and meta-analysis. J. Cell. Mol. Med. 2021, 25, 2750-2763, https://doi.org/10.1111/jcmm.16334.

9. Lin, S.-R.; Chang, C.-H.; Hsu, C.-F.; Tsai, M.-J.; Cheng, H.; Leong, M.K.; Sung, P.-J.; Chen, J.-C.; Weng, C.-F. Natural compounds as potential adjuvants to cancer therapy: Preclinical evidence. Br. J. Pharmacol. 2020, 177, 1409-1423, https://doi.org/10.1111/bph.14816.

10. Fontana, F.; Raimondi, M.; Marzagalli, M.; Di Domizio, A.; Limonta, P. Natural Compounds in Prostate Cancer Prevention and Treatment: Mechanisms of Action and Molecular Targets. Cells 2020, 9 , https://doi.org/10.3390/cells9020460.

11. Gökalp, F. The effective natural compounds for inhibiting Cervical cancer. Med. Oncol. 2021, 38, 12, https://doi.org/10.1007/s12032-021-01456-3.

12. Liskova, A.; Koklesova, L.; Samec, M.; Smejkal, K.; Samuel, S.M.; Varghese, E.; Abotaleb, M.; Biringer, K.; Kudela, E.; Danko, J.; Shakibaei, M.; Kwon, T.K.; Büsselberg, D.; Kubatka, P. Flavonoids in Cancer Metastasis. Cancers (Basel) 2020, 12, https://doi.org/10.3390/cancers12061498.

13. Khan, H.; Belwal, T.; Efferth, T.; Farooqi, A.A.; Sanches-Silva, A.; Vacca, R.A.; Nabavi, S.F.; Khan, F.; Prasad Devkota, H.; Barreca, D.; Sureda, A.; Tejada, S.; Dacrema, M.; Daglia, M.; Suntar, İ; Xu, S.; Ullah, H.; Battino, M.; Giampieri, F.; Nabavi, S.M. Targeting epigenetics in cancer: therapeutic potential of flavonoids. Crit. Rev. Food Sci. Nutr. 2021, 61, 1616-1639, https://doi.org/10.1080/10408398.2020.1763910.

14. Yu, G.; Chen, L.; Hu, Y.; Yuan, Z.; Luo, Y.; Xiong, Y. Antitumor Effects of Baicalein and Its Mechanism via TGF $\beta$ Pathway in Cervical Cancer HeLa Cells. Evid. Based Complement. Alternat. Med. 2021, 2021, 5527190, https://doi.org/10.1155/2021/5527190.

15. Wang, B.; Qu, J.; Luo, S.; Feng, S.; Li, T.; Yuan, M.; Huang, Y.; Liao, J.; Yang, R.; Ding, C. Optimization of Ultrasound-Assisted Extraction of Flavonoids from Olive (Olea europaea) Leaves, and Evaluation of Their Antioxidant and Anticancer Activities. Molecules 2018, 23, https://doi.org/10.3390/molecules23102513.

16. Pandey, P.; Khan, F.; Mazumder, A.; Rana, A.K.; Srivastava, Y. Inhibitory Potential of Dietary Phytocompounds of Nigella sativa against Key Targets of Novel Coronavirus (COVID-19). Indian Journal of Pharmaceutical Education and Research 2021, 55, 190-197, https://doi.org/10.5530/ijper.55.1.21.

17. Pandey, P.; Khan, F.; Rana, A.K.; Srivastava, Y.; Jha, S.K.; Jha, N.K. A drug repurposing approach towards elucidating the potential of flavonoids as COVID-19 spike protein inhibitors. Biointerface Res. Appl. Chem 2021, 11, 8482-8501, https://doi.org/10.33263/BRIAC111.84828501.

18. Vibala, B.V.; Praseetha, P.K.; Vijayakumar, S. Evaluating new strategies for anticancer molecules from ethnic medicinal plants through in silico and biological approach-A review. Gene Rep. 2020, 18, 100553, https://doi.org/10.1016/j.genrep.2019.100553.

19. Pandey, P.; Singhal, D.; Khan, F.; Arif, M. An in silico screening on piper nigrum, syzygium aromaticum and zingiber officinale roscoe derived compounds against sars-cov-2: A drug repurposing approach. Biointerface Res. Appl. Chem 2021, 11, 11122-11134, https://doi.org/10.33263/BRIAC114.1112211134.

20. Ahmad, S.; Abbasi, H.W.; Shahid, S.; Gul, S.; Abbasi, S.W. Molecular docking, simulation and MM-PBSA studies of nigella sativa compounds: a computational quest to identify potential natural antiviral for COVID19 treatment. J. Biomol. Struct. Dyn. 2020, 1-9, https://doi.org/10.1080/07391102.2020.1775129.

21. Morris, G.M.; Goodsell, D.S.; Halliday, R.S.; Huey, R.; Hart, W.E.; Belew, R.K.; Olson, A.J. Automated docking using a Lamarckian genetic algorithm and an empirical binding free energy function. J. Comput. Chem. 1998, 19, 1639-1662, https://doi.org/10.1002/(SICI)1096-987X(19981115)19:14<1639::AIDJCC10>3.0.CO;2-B.

22. Siddiqui, S.; Upadhyay, S.; Ahmad, R.; Gupta, A.; Srivastava, A.; Trivedi, A.; Husain, I.; Ahmad, B.; Ahamed, M.; Khan, M.A. Virtual screening of phytoconstituents from miracle herb nigella sativa targeting nucleocapsid protein and papain-like protease of SARS-CoV-2 for COVID-19 treatment. J. Biomol. Struct. Dyn. 2020, https://doi.org/10.1080/07391102.2020.1852117.

23. Lipinski, C.A. Lead- and drug-like compounds: the rule-of-five revolution. Drug Discovery Today: Technologies 2004, 1, 337-341, https://doi.org/10.1016/j.ddtec.2004.11.007.

24. Proudfoot, A.E.I. Chemokine receptors: multifaceted therapeutic targets. Nature Reviews Immunology 2002, 2, 106-115, https://doi.org/10.1038/nri722. 
25. Tian, S.; Wang, J.; Li, Y.; Li, D.; Xu, L.; Hou, T. The application of in silico drug-likeness predictions in pharmaceutical research. Adv. Drug Del. Rev. 2015, 86, 2-10, https://doi.org/10.1016/j.addr.2015.01.009.

26. Pratibha, P.; Mohammad, H.S.; Anu, B.; Vinay, K.K.; Kumudesh, M.; Uzma, S.; Rohit, K.T.; Rafia, S.; Preeti, B. Jab1-siRNA Induces Cell Growth Inhibition and Cell Cycle Arrest in Gall Bladder Cancer Cells via Targeting Jab1 Signalosome. Anticancer Agents Med. Chem. 2019, 19, 2019-2033, https://doi.org/10.2174/1871520619666190725122400.

27. Pratibha, P.; Preeti, B.; Mohammad, H.S.; Uzma, S.; Rohit, T.; Rafia, S.; Kumudesh, M.; Kapoor, V.K. Elucidation of the Chemopreventive Role of Stigmasterol Against Jab1 in Gall Bladder Carcinoma. Endocrine, Metabolic \& Immune Disorders - Drug Targets 2019, 19, 826-837, https://doi.org/10.2174/1871530319666190206124120.

28. Yu, X.; Yang, Y.; Li, Y.; Cao, Y.; Tang, L.; Chen, F.; Xia, J. Baicalein inhibits cervical cancer progression via downregulating long noncoding RNA BDLNR and its downstream PI3K/Akt pathway. The International Journal of Biochemistry \& Cell Biology 2018, 94, 107-118, https://doi.org/10.1016/j.biocel.2017.11.009.

29. Lue, H.; Thiele, M.; Franz, J.; Dahl, E.; Speckgens, S.; Leng, L.; Fingerle-Rowson, G.; Bucala, R.; Lüscher, B.; Bernhagen, J. Macrophage migration inhibitory factor (MIF) promotes cell survival by activation of the Akt pathway and role for CSN5/JAB1 in the control of autocrine MIF activity. Oncogene 2007, 26, 50465059, https://doi.org/10.1038/sj.onc.1210318. 